\title{
Hydroxoiridium-Catalyzed Hydroarylation of Alkynes and Bicycloalkenes with $\mathrm{N}$-Sulfonylbenzamides
}

\author{
Midori Nagamoto, Jun-ichi Fukuda, Miyuki Hatano, \\ Hideki Yorimitsu, Takahiro Nishimura
}

\begin{tabular}{|c|l|}
\hline Citation & Organic Letters, 19(21); 5952-5955 \\
\hline Issue Date & $2017-10-19$ \\
\hline Type & Journal Article \\
\hline Textversion & author \\
\hline \multirow{2}{*}{ Rights } & $\begin{array}{l}\text { This document is the Accepted Manuscript version of a Published Work that appeared } \\
\text { in final form in Organic Letters, copyright } @ \text { American Chemical Society after peer } \\
\text { review and technical editing by the publisher. To access the final edited and published } \\
\text { work see https://doi.org/10.1021/acs.orglett.7b02950 }\end{array}$ \\
\hline DOI & \begin{tabular}{l} 
10.1021/acs.orglett.7b02950 \\
\hline
\end{tabular} \\
\hline
\end{tabular}

\author{
Self-Archiving by Author(s) \\ Placed on: Osaka City University
}




\title{
Hydroxoiridium-Catalyzed Hydroarylation of Alkynes and Bicyclo- alkenes with $\mathrm{N}$-Sulfonylbenzamides
}

\author{
Midori Nagamoto, ${ }^{\dagger}$ Jun-ichi Fukuda ${ }^{\dagger}$ Miyuki Hatano, ${ }^{\dagger}$ Hideki Yorimitsu, ${ }^{\dagger}$ and Takahiro Nishimura ${ }^{\ddagger *}$ \\ ${ }^{\dagger}$ Department of Chemistry, Graduate School of Science, Kyoto University, Sakyo, Kyoto 606-8502, Japan \\ ${ }^{\ddagger}$ Department of Chemistry, Graduate School of Science, Osaka City University, Sumiyoshi, Osaka 558-8585 Japan \\ Supporting Information Placeholder
}

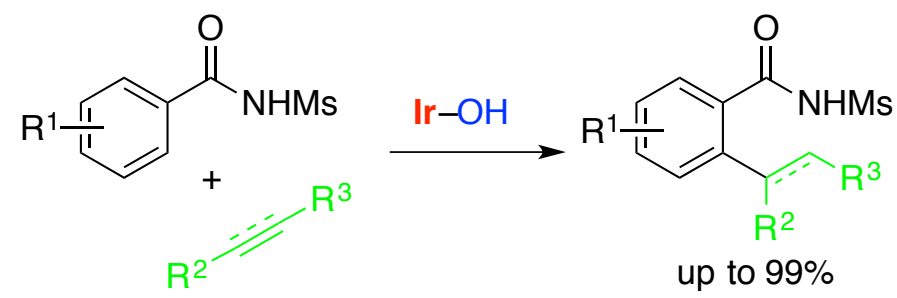

ABSTRACT: Hydroxoiridium complexes efficiently catalyzed the hydroarylation of alkynes and bicycloalkenes with $N$ sulfonylbenzamides via $\mathrm{C}-\mathrm{H}$ activation to give the corresponding ortho-alkenylation and alkylation products in high yields.

Transition metal-catalyzed direct functionalization of unactivated aromatic $\mathrm{C}-\mathrm{H}$ bonds has been attracting significant attention from the aspect of atom- and step-economy. Catalytic hydroarylation of $\mathrm{C}-\mathrm{C}$ unsaturated bonds through chelationassisted $\mathrm{C}-\mathrm{H}$ bond activation ${ }^{1}$ has been widely investigated since the pioneering studies on Ru catalysis. ${ }^{1 \mathrm{j}, \mathrm{k}}$ In this context, hydroarylation of alkynes ${ }^{2-8}$ has also been developed by using a variety of transition metal catalysts such as $\mathrm{Ru},{ }^{2} \mathrm{Rh},{ }^{3} \mathrm{Pd},{ }^{4} \mathrm{Ir},{ }^{5}$ $\mathrm{Ni}^{6}{ }^{6}$ and Co. ${ }^{7}$ Several catalyst systems enabled one-pot synthesis of (hetero)cyclic compounds via hydroarylation/intramolecular cyclization sequence. ${ }^{9,10}$

Recently, we reported iridium-catalyzed hydroarylation of vinyl ethers with high branch selectivity, ${ }^{11}$ and found that hydroxoiridium complexes efficiently catalyzed hydroarylation with $N$-sulfonylbenzamides ${ }^{11 \mathrm{~b}}$ and aryl-substituted azoles ${ }^{11 \mathrm{c}}$ bearing an $\mathrm{N}-\mathrm{H}$ bond as a directing group, where the key intermediate for $\mathrm{C}-\mathrm{H}$ activation is an amidoiridium(I) species generated in situ by deprotonation (Scheme 1). We next focused on the development of hydroarylation of unsaturated compounds other than vinyl ethers by way of the amidoiridi-

Scheme 1. $\operatorname{Ir}(\mathrm{OH})$-Catalyzed C-H Functionalization

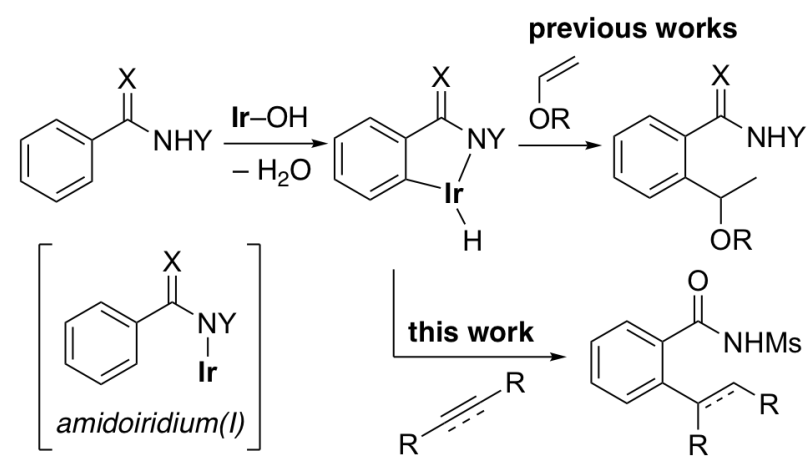

um(I) intermediate. Here we report the hydroarylation of alkynes and bicycloalkenes with $\mathrm{N}$-sulfonylbenzamides catalyzed by hydroxoiridium complexes.

Treatment of 3-methyl- $N$-(methanesulfonyl)benzamide (1a) with 1.1 equiv of diphenylacetylene (2a) in the presence of $[\operatorname{Ir}(\mathrm{OH})(\mathrm{cod})]_{2}(2 \mathrm{~mol} \% \mathrm{Ir}, \mathrm{cod}=1,5$-cyclooctadiene $)$ in toluene at $70{ }^{\circ} \mathrm{C}$ for $1 \mathrm{~h}$ gave an $98 \%$ yield of adduct 3 aa as a sole addition product (Table 1, entry 1). ${ }^{12}$ Although a chloroiridi-

Table 1. Hydroarylation of 2 a with $1 a^{a}$

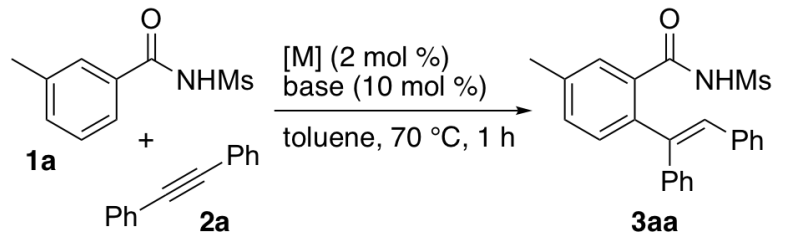

$\begin{array}{llll}\text { entry } & \text { catalyst } & \text { base } & \text { yield (\%) } \\ 1 & {[\operatorname{Ir}(\mathrm{OH})(\mathrm{cod})]_{2}} & - & 98^{b} \\ 2 & {[\mathrm{IrCl}(\mathrm{cod})]_{2}} & - & 26 \\ 3 & {[\mathrm{IrCl}(\mathrm{cod})]_{2}} & \mathrm{Et}_{3} \mathrm{~N} & 54 \\ 4 & {[\mathrm{IrCl}(\mathrm{cod})]_{2}} & \mathrm{~K}_{2} \mathrm{CO}_{3} & 84 \\ 5 & {\left[\mathrm{IrCl}(\mathrm{coe})_{2}\right]_{2}} & \mathrm{~K}_{2} \mathrm{CO}_{3} & 0 \\ 6 & {[\mathrm{Ir}(\mathrm{OH})(\mathrm{cod})]_{2} /(\mathrm{rac}) \text {-binap }} & - & 0 \\ 7 & {[\mathrm{Rh}(\mathrm{OH})(\mathrm{cod})]_{2}} & - & 0 \\ 8^{c} & {[\mathrm{Ir}(\mathrm{OH})(\mathrm{cod})]_{2}} & - & 99\end{array}$

${ }^{a}$ Reaction conditions: 1a $(0.20 \mathrm{mmol}), \mathbf{2 a}(0.22 \mathrm{mmol})$, catalyst $(2 \mathrm{~mol} \%)$, and base $(10 \mathrm{~mol} \%)$ in toluene $(0.80 \mathrm{~mL})$ at $70{ }^{\circ} \mathrm{C}$ for $1 \mathrm{~h}$. The yields were determined by ${ }^{1} \mathrm{H}$ NMR by using $p$-dimethoxybenzene as an internal standard. ${ }^{b}$ Isolated yield. ${ }^{c}$ At $20^{\circ} \mathrm{C}$ for $4 \mathrm{~h}$. 
um complex $[\mathrm{IrCl}(\operatorname{cod})]_{2}$ was much less effective in catalyzing the reaction than $[\operatorname{Ir}(\mathrm{OH})(\mathrm{cod})]_{2}$ (entry 2), the presence of a catalytic amount of bases, such as $\mathrm{Et}_{3} \mathrm{~N}$ and $\mathrm{K}_{2} \mathrm{CO}_{3}$, accelerated the reaction (entries 3 and 4). The present reaction requires a chelating diene ligand as the use of $\left[\mathrm{IrCl}(\mathrm{coe})_{2}\right]_{2}$ in the presence of $\mathrm{K}_{2} \mathrm{CO}_{3}$ resulted in no reaction (entry 5). A hydroxoiridium/bisphosphine complex and a hydroxorhodium complex did not exhibit any catalytic activity (entries 6 and 7). It should be noted that the reaction proceeded smoothly even at $20{ }^{\circ} \mathrm{C}$ and completed within $4 \mathrm{~h}$ (entry 8 ).

The results obtained for the iridium-catalyzed hydroarylation of diphenylacetylene (2a) with several benzamides $\mathbf{1}$ are summarized in Scheme 2. The reactions of meta-substituted benzamides $\mathbf{1 b}-\mathbf{1 f}$ gave the corresponding adducts $\mathbf{3 b a}-\mathbf{3 f a}$ in high yields. For hydroarylation with unsubstituted benzamide $\mathbf{1 g}$, the reaction conditions were modified because $\mathbf{1 g}$ underwent double hydroarylation under the standard reaction conditions to give a mixture of monoalkenylated amide 3ga and dialkenylated amide $\mathbf{4 g a}:{ }^{13}$ the use of slight excess of $\mathbf{1 g}$ at $30{ }^{\circ} \mathrm{C}$ suppressed the second hydroarylation to give $\mathbf{3 g a}$ in $82 \%$ yield. The double alkenylation was achieved by using 2.4 equiv of $\mathbf{2 a}$, thus giving $\mathbf{4 g a}$ in $88 \%$ yield. A sterically demanding ortho-substituent in $\mathbf{1 h}$ did not affect the reaction. Amides 1i-1l bearing a naphthyl and heteroaromatic rings were also good substrates for the present reaction. The reaction of $N$-( $p$-toluenesulfonyl)benzamide $\mathbf{1 m}$ also gave the ad-

Scheme 2. Hydroarylation of $2^{a}$

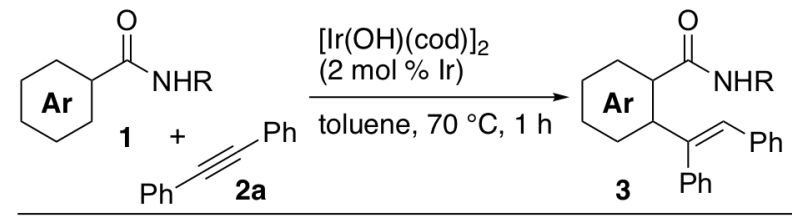

$\mathrm{R}=\mathrm{Ms}, \mathrm{Ar}=3-\mathrm{ClC}_{6} \mathrm{H}_{4}(\mathbf{1 b}), 3-\mathrm{BrC}_{6} \mathrm{H}_{4}(\mathbf{1 c}), 3-\mathrm{CF}_{3} \mathrm{C}_{6} \mathrm{H}_{4}(\mathbf{1 d})$, 3- $\mathrm{MeOC}_{6} \mathrm{H}_{4}$ (1e), 3-PhC ${ }_{6} \mathrm{H}_{4}$ (1f), $\mathrm{Ph}(\mathbf{1 g}), 2-\mathrm{MeC}_{6} \mathrm{H}_{4}$ (1h), 1-naphthyl (1i), 2-naphthyl (1j), 2-furyl (1k), 2-thienyl (1) $\mathrm{R}=\mathrm{Ts}, \mathrm{Ar}=3-\mathrm{MeC}_{6} \mathrm{H}_{4}(\mathbf{1 m})$

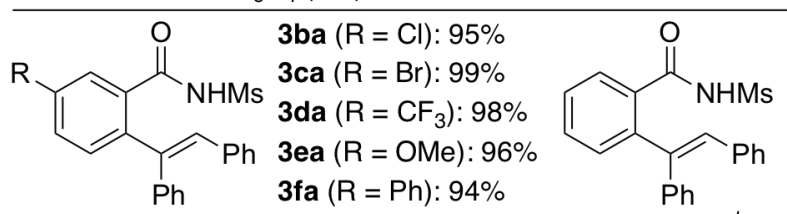<smiles>CNC(=O)c1c(/C(=C/c2ccccc2)c2ccccc2)cccc1/C(=C/c1ccccc1)c1ccccc1</smiles>

4ga: $88 \%^{c}$<smiles>CNC(=O)c1c(C)cccc1/C(=C/c1ccccc1)c1ccccc1</smiles>

3ha: $97 \%$

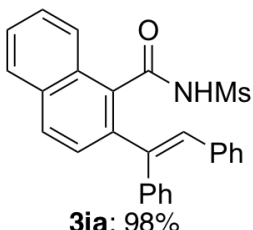<smiles>CNC(=O)c1cc2ccccc2cc1/C(=C/c1ccccc1)c1ccccc1</smiles><smiles></smiles>
3ka $(\mathrm{X}=\mathrm{O})$ : $96 \%{ }^{d}$ 3la $(X=S): 94 \%{ }^{d}$<smiles>CNC(=O)c1cc(C)ccc1/C(=C/c1ccccc1)c1ccccc1</smiles>

3ma: $96 \%^{e}$ 3ja: $99 \%$$$
\text { ( } X=S): 94 \% d
$$

${ }^{a}$ Reaction conditions: $1(0.20 \mathrm{mmol}), \mathbf{2 a}(0.22 \mathrm{mmol})$, and $[\operatorname{Ir}(\mathrm{OH})(\mathrm{cod})]_{2}(2 \mathrm{~mol} \% \mathrm{Ir})$ in toluene $(0.80 \mathrm{~mL})$ at $70{ }^{\circ} \mathrm{C}$ for 1 h. ${ }^{b} \mathbf{1 g}(0.22 \mathrm{mmol}), 2 \mathrm{a}(0.20 \mathrm{mmol})$, and $[\operatorname{Ir}(\mathrm{OH})(\operatorname{cod})]_{2}(5$ mol \% Ir) in dichloromethane at $30{ }^{\circ} \mathrm{C}$ for $20 \mathrm{~h} .{ }^{c} \mathbf{1 g}(0.20$ $\mathrm{mmol}), 2 \mathrm{a}(0.48 \mathrm{mmol})$, and $[\mathrm{Ir}(\mathrm{OH})(\mathrm{cod})]_{2}(5 \mathrm{~mol} \% \mathrm{Ir})$ at $80{ }^{\circ} \mathrm{C}$ for $20 \mathrm{~h} .{ }^{d}$ For $3 \mathrm{~h} .{ }^{e}$ For $6 \mathrm{~h}$. duct $3 \mathbf{m a}$ in $96 \%$ yield.

Table 2 summarizes the results obtained for the reaction of amide $\mathbf{1 a}$ with several alkynes 2 . The reactions of diarylacetylenes bearing halogen substituents, electron-withdrawing and donating substituents proceeded smoothly to give the adducts in high yields (entries 1-9). Dialkylacetylene 3k also participated in the reaction to give the syn-adduct 3ak in $93 \%$ yield (entry 10).

The reactions of unsymmetrically-substituted alkynes gave the alkenylation products as a mixture of regioisomers (Table 3 ). In the reactions of 1-aryl-1-propynes, $\mathrm{C}-\mathrm{C}$ bond formation preferentially occurred at the $\mathrm{C} 2$ position although electronwithdrawing substituents on the aryl group of the alkyne $2 \mathbf{n}$ significantly decreased the regioselectivity (entries 1-3). In the case of unsymmetrically substituted diarylacetylenes, $\mathrm{C}-\mathrm{C}$ bond formation occurred at the carbon adjacent to the elec-

Table 2. Hydroarylation of various alkynes ${ }^{a}$

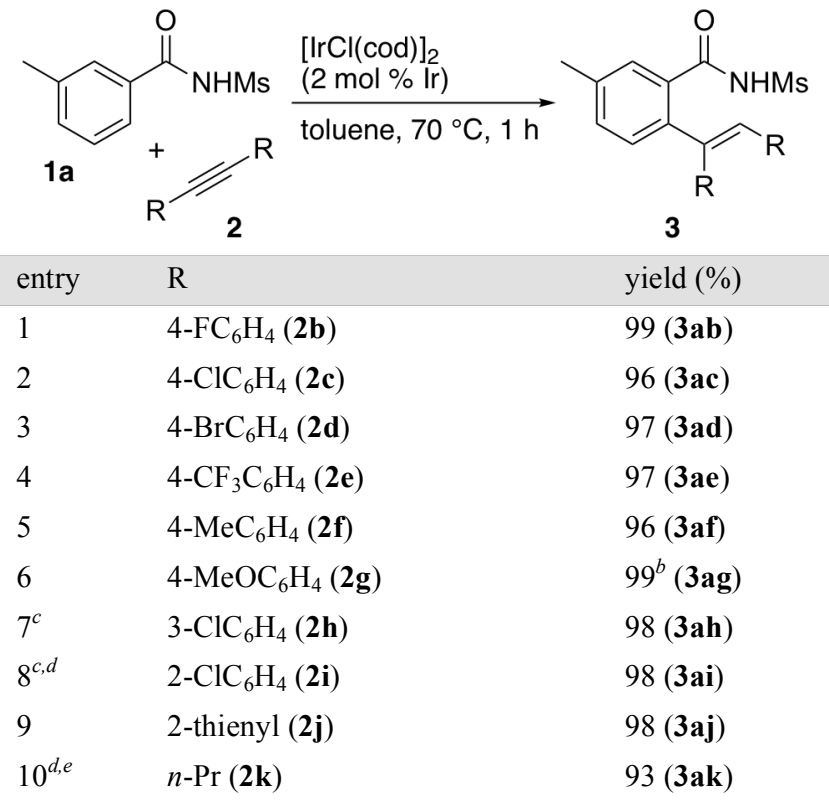

${ }^{a}$ Reaction conditions: 1a $(0.20 \mathrm{mmol}), 2(0.22 \mathrm{mmol})$, and $[\mathrm{Ir}(\mathrm{OH})(\mathrm{cod})]_{2}(2 \mathrm{~mol} \% \mathrm{Ir})$ in toluene $(0.80 \mathrm{~mL})$ at $70{ }^{\circ} \mathrm{C}$ for 1 h. Isolated yields are shown. ${ }^{b}$ Isolated yield after $N$ methylation. See the Supporting Information. ${ }^{c}$ For $2 \mathrm{~h} .{ }^{d}$ At $30{ }^{\circ} \mathrm{C}$. ${ }^{e} \mathrm{In}$ dichloromethane for $20 \mathrm{~h}$.

Table 3. Hydroarylation of Unsymmetrical Alkynes ${ }^{a}$

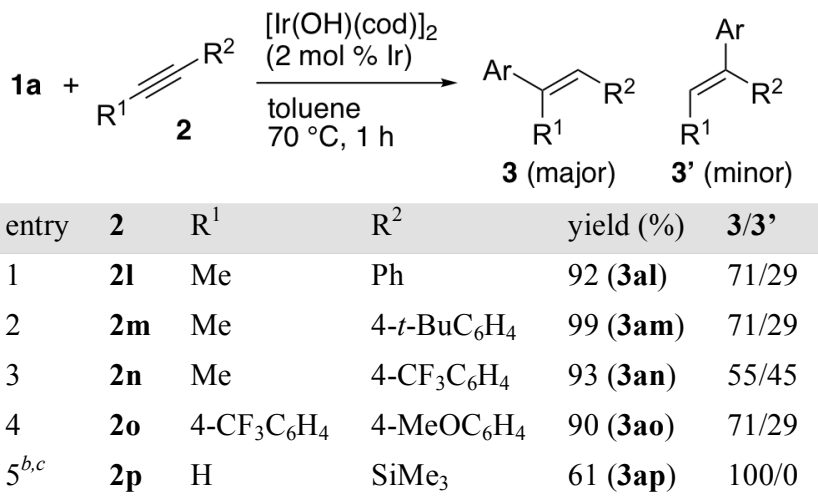

${ }^{a}$ Reaction conditions: $1 \mathrm{a}(0.20 \mathrm{mmol}), 2(0.22 \mathrm{mmol})$, and $[\operatorname{Ir}(\mathrm{OH})(\mathrm{cod})]_{2}(2 \mathrm{~mol} \% \mathrm{Ir})$ in toluene $(0.80 \mathrm{~mL})$ at $70{ }^{\circ} \mathrm{C}$ for 1 h. Isolated yields are shown. ${ }^{b}$ For $20 \mathrm{~h} .{ }^{c} \mathbf{2 p}$ was added in three portions every $5 \mathrm{~h}$. 
Table 4. Hydroarylation of Bicycloalkenes ${ }^{a}$

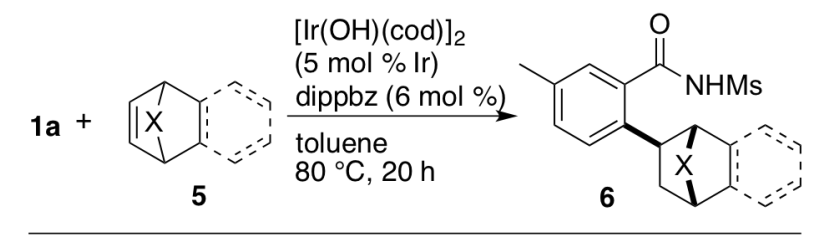

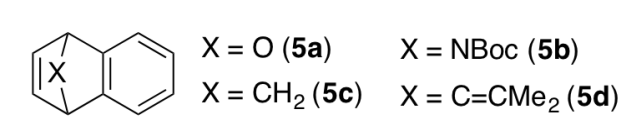

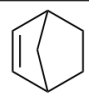

$\begin{array}{lll}\text { entry } & \mathbf{5} & \text { yield }(\%) \\ 1 & \mathbf{5 a} & 88(\mathbf{6 a a}) \\ 2 & \mathbf{5 b} & 96(\mathbf{6 a b}) \\ 3 & \mathbf{5 c} & 97(\mathbf{6 a c}) \\ 4 & \mathbf{5 d} & 98(\mathbf{6 a d}) \\ 5^{b} & \mathbf{5 e} & 96(\mathbf{6 a e})\end{array}$

${ }^{a}$ Reaction conditions: 1a $(0.20 \mathrm{mmol}), 5$ (0.30 $\left.\mathrm{mmol}\right)$, $[\operatorname{Ir}(\mathrm{OH})(\mathrm{cod})]_{2}(5 \mathrm{~mol} \% \mathrm{Ir})$, and dippbz $(6 \mathrm{~mol} \%)$ in toluene $(0.80 \mathrm{~mL})$ at $70{ }^{\circ} \mathrm{C}$ for $1 \mathrm{~h}$. Isolated yields are shown. Dippbz $=1,2-\mathrm{Bis}$ (diisopropylphosphino)benzene. ${ }^{b}$ At $70{ }^{\circ} \mathrm{C}$ for $1 \mathrm{~h}$.

tron-deficient aryl group (entry 4). The reaction of trimethylsilylacetylene (2p) gave $\mathbf{3 a p}$ as a single regioisomer (entry 5). These results indicate that the regioselectivity of the present reaction is influenced by both steric and electronic factors.

The hydroxoiridium complex can also catalyze diastereoselective hydroarylation of bicycloalkenes. Although $[\operatorname{Ir}(\mathrm{OH})(\mathrm{cod})]_{2}$ exhibited only moderate catalytic activity, the use of 1,2-bis(diisopropylphosphino)benzene (dippbz) as a ligand was found to be effective for the hydroarylation of various bicycloalkenes 5 (Table 4). Oxabenzonorbornadiene (4a), azabenzonorbornadiene (4b), benzonorbornene (5c), and its analogue $\mathbf{5 d}$ reacted to give $\mathbf{6 a a - 6 a d}$ in high yields (entries $1-$ 4). The reaction of norbornene (5e) also proceeded well to give 6 ae in $96 \%$ yield (entry 5 ). The adducts 6 possess stereocenters, and thus enantioselective hydroarylation of bicycloalkenes is our next target. ${ }^{14}$ A preliminary experiment showed that $(R, R)$-Quinox $\mathrm{P}^{* 15}$ was a promising ligand for the asymmetric hydroarylation of norbornene (5e) with $\mathbf{1 a}(\mathrm{eq} 1)$.

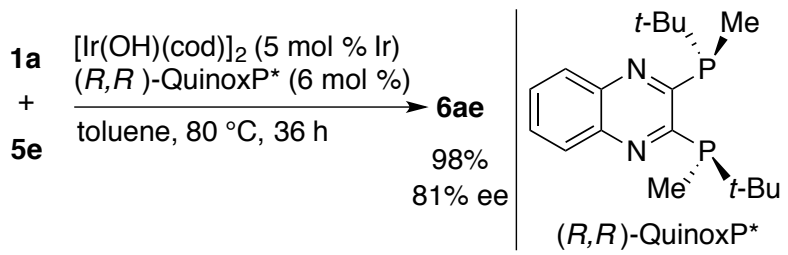

A plausible catalytic cycle is shown in Scheme 3. A hydroxoiridium complex reacts with $N$-sulfonylbenzamide 1 to give an amidoiridium species $\mathbf{A}$ along with the formation of $\mathrm{H}_{2} \mathrm{O} .{ }^{11 \mathrm{a}}$ Oxidative addition of ortho- $\mathrm{C}-\mathrm{H}$ bond to the iridium gives a hydridoiridium(III) intermediate $\mathbf{B},{ }^{16}$ which reacts with alkyne 2 to generate the intermediate $\mathbf{C} .^{9 \mathrm{~g}}$ Reductive elimination and ligand exchange by the amide $\mathbf{1}$ gives the adduct $\mathbf{3}$ and regenerates the amidoiridium species $\mathbf{A}$.

It was found that the reaction rate is apparently independent of the substrate concentration: when the reaction of $\mathbf{1 d}$ with $\mathbf{2 a}$ in $\mathrm{CD}_{2} \mathrm{Cl}_{2}$ was monitored by ${ }^{1} \mathrm{H} \mathrm{NMR}$, the yield of $\mathbf{3 d a}$ showed a linear increase with time (Figure 1). This result
Scheme 3. Plausible Catalytic Cycle
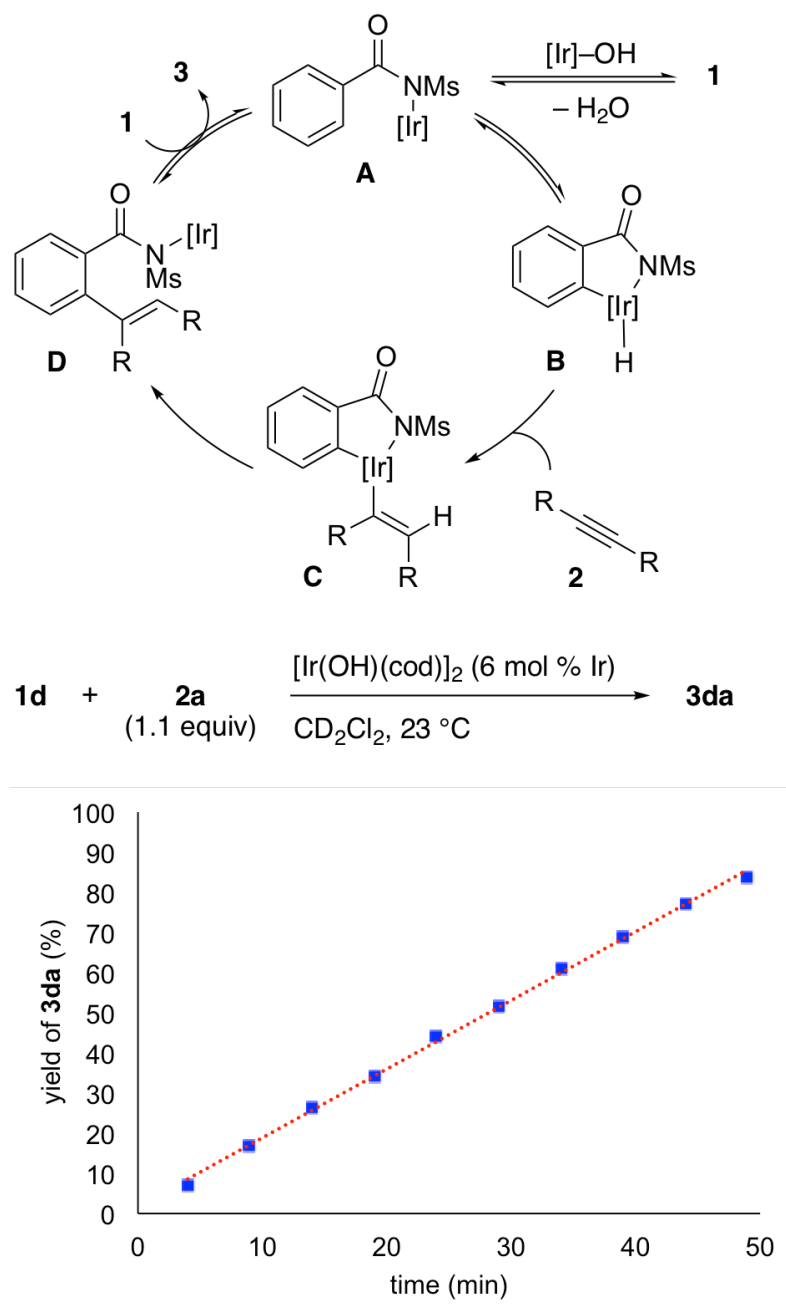

Figure 1. Plot of the yield of $\mathbf{3 d a}$ vs time. Reaction conditions: 1d $(0.050 \mathrm{mmol}), \mathbf{2 a}(0.055 \mathrm{mmol})$, and $[\operatorname{Ir}(\mathrm{OH})(\operatorname{cod})]_{2}$ $(6 \mathrm{~mol} \% \mathrm{Ir})$ in $\mathrm{CD}_{2} \mathrm{Cl}_{2}(0.70 \mathrm{~mL})$ at $23{ }^{\circ} \mathrm{C}$.

implies that reductive elimination is the turnover-limiting step in the present reaction.

To gain further insight into the reaction mechanism, we investigated the electronic effect of the substituents on the aryl ring of the amide $\mathbf{1}$. In two separate reactions of $\mathbf{1 a}$ and $\mathbf{1 d}$, bearing methyl and trifluoromethyl groups, no significant difference in the reactivity was observed (see Table S2). This result implies that the electronic nature of the amide has little effect on the rate of reductive elimination. In contrast, intermolecular competition experiments revealed that electrondeficient amide preferentially reacted to give the corresponding hydroarylation product $\mathbf{3}$, where a Hammett plot vs. $\sigma$ values showed a correlation $\left(\rho=1.14, R^{2}=0.89\right.$ : see Table $\mathrm{S} 3)^{21}$ The difference in reactivity observed in the intermolecular competition experiments might be due to reversible steps (i.e. formation of amidoiridium $\mathbf{A}$ and $\mathrm{C}-\mathrm{H}$ activation) preceding reductive elimination.

In conclusion, we developed the hydroxoiridium-catalyzed hydroarylation of alkynes and bicycloalkenes with $N$ sulfonylbenzamides via $\mathrm{C}-\mathrm{H}$ activation. An iridium/cod complex efficiently catalyzed hydroarylation of various alkynes. 
Hydroarylation of bicycloalkenes also proceeded smoothly by using dippbz as a ligand.

\section{ASSOCIATED CONTENT}

\section{Supporting Information}

The Supporting Information is available free of charge on the ACS Publications website.

Experimental procedures and compound characterization (PDF) Compound characterization (CIF)

\section{AUTHOR INFORMATION}

\section{Corresponding Author}

*E-mail: tnishi@sci.osaka-cu.ac.jp

\section{ACKNOWLEDGMENT}

This work was supported by JSPS KAKENHI Grant Number JP15H03810. M.N. thanks the JSPS for Research Fellowship for Young Scientists.

\section{REFERENCES}

1 For selected recent reviews, see: (a) Crisenza, G. E. M.; Bower, J. F. Chem. Lett. 2016, 45, 2. (b) Moselage, M.; Li, J.; Ackermann, L. ACS Catal. 2016, 6, 498. (c) Huang, Z.; Lim, H. N.; Mo, F.; Young, M. C.; Dong, G. Chem. Soc. Rev. 2015, 44, 7764. (d) Chen, Z.; Wang, B.; Zhang, J.; Yu, W.; Liu, Z.; Zhang, Y. Org. Chem. Front. 2015, 2, 1107. (e) Manikanadan, R.; Jeganmohan, M. Org. Biomol. Chem. 2015, 13, 10420. (f) Zheng, Q.-Z.; Jiao, N. Tetrahedron Lett. 2014, 55, 1121. (g) Zhang, X. Chem. Rev. 2013, 113, 6864. (h) Arockiam, P. B.; Bruneau, C.; Dixneuf, P. H. Chem. Rev. 2012, 112, 5879. (i) Nevado, C.; Echavarren, A. M. Synthesis 2005, 167. For the pioneering work, see: (j) Lewis, L. N.; Smith, J. F. J. Am. Chem. Soc. 1986, 108, 2728. (k) Murai, S.; Kakiuchi, F.; Sekine, S.; Tanaka, Y.; Kamatani, A.; Sonoda, M.; Chatani, N. Nature 1993, 366, 529.

2 (a) Kakiuchi, F.; Yamamoto, Y.; Chatani, N.; Murai, S. Chem. Lett. 1995, 24, 681. (b) Cheng, K.; Yao, B.; Zhao, J.; Zhang, Y. Org. Lett. 2008, 10, 5309. (c) Hashimoto, Y. Hirano, K.; Satoh, T.; Kakiuchi, F.; Miura, M. Org. Lett. 2012, 14, 2058. (d) Zhao, P.; Niu, R.; Wang, F.; Han, K.; Li, X. Org. Lett. 2012, 14, 4166. (e) Reddy, M. C.; Jeganmohan, M. Chem. Commun. 2013, 49, 481. (f) Suzuki, C.; Hirano, K.; Satoh, T.; Miura, M. Org. Lett. 2013, 15, 3990. (g) Manikandan, R.; Jeganmohan, M. Org. Lett. 2014, 16, 912. (h) Liang, L.; Fu, S.; Lin, D.; Zhang, X.-Q.; Deng, Y.; Jiang, H.; Zeng, W. J. Org. Chem. 2014, 79, 9472. (i) Min, M.; Kim, D.; Hong, S. Chem. Commun. 2014, 50, 8028. (j) Padala, K.; Jeganmohan, M. Chem. Commun. 2014, 50, 14573. (k) Villuendas, P.; Urriolabeitia, E. P. Org. Lett. 2105, 17, 3178. (1) Hu, F.; Szostak, M. Chem. Commun. 2016, 52, 9715. (m) Huang, L.; Biafora, A.; Zhang, G.; Bragoni, V.; Gooßen, L. J. Angew. Chem., Int. Ed. 2016, 55, 6933. (n) Miura, H.; Terajima, S.; Tsutsui, K.; Shishido, T. J. Org. Chem. 2017, 82, 1231.

3 (a) Lim, Y.-G.; Lee, K.-H.; Koo, B. T.; Kang, J.-B. Tetrahedron Lett. 2001, 42, 7609. (b) Katagiri, T.; Mukai, T.; Satoh, T.; Hirano, K.; Miura, M. Chem. Lett. 2009, 38, 118. (c) Schipper, D. J.; Hutchinson, M.; Fagnou, K. J. Am. Chem. Soc. 2010, 132, 6910. (d) Kwak, J.; Ohk, Y.; Jung, Y.; Chang, S. J. Am. Chem. Soc. 2012, 134, 17778. (e) Shibata, T.; Takayasu, S.; Yuzawa, S.; Otani, T. Org. Lett. 2012, 14, 5106. (f) Zhou, W.; Yang, Y.; Wang, Z.; Deng, G.-J. Org. Biomol. Chem. 2014, 12, 251. (g) Liu, B.; Zhou, T.; Li, B.; Xu, S.; Song, H.; Wang, B. Angew. Chem., Int. Ed. 2014, 53, 4191. (h) Nobushige, K.; Hirano, K.; Satoh, T.; Miura, M. Org. Lett. 2014, 16, 1188. (i) Martínez, A. M.; Echavarren, J.; Alonso, I.; Rodoríguez, N.; Arrayás, R. G.; Carretero, J. C. Chem. Sci. 2015, 6, 5802.
4 (a) Jia, C.; Piao, D.; Oyamada, J.; Lu, W.; Kitamura, T.; Fujiwara, Y. Science 2000, 287, 1992. (b) Tsukada, N.; Mitsuboshi, T.; Setoguchi, H.; Inoue, Y. J. Am. Chem. Soc. 2003, 125, 12102. (c) Chernyak, N.; Gevorgyan, V. J. Am. Chem. Soc. 2008, 130, 5636.

5 (a) Satoh, T.; Nishinaka, Y.; Miura, M.; Nomura, M. Chem. Lett. 1999, 28, 615. (b) Nishinaka, Y.; Satoh, T.; Miura, M.; Morisaka, H.; Nomura, M.; Matsui, H.; Yamaguchi, C. Bull. Chem. Soc. Jpn. 2001, 74, 1727. (c) Tsuchikama, K.; Kasagawa, M.; Hashimoto, Y.; Endo, K.; Shibata, T. J. Organomet. Chem. 2008, 693, 3939.

6 (a) Nakao, Y.; Kanyiva, K. S.; Hiyama, T. J. Am. Chem. Soc. 2008, 130, 2448. (b) Nakao, Y.; Idei, H.; Kanyiva, K. S.; Hiyama, T. J. Am. Chem. Soc. 2009, 131, 15996.

7 (a) Gao, K.; Lee, P.-S.; Fujita, T.; Yoshikai, N. J. Am. Chem. Soc. 2010, 132, 12249. (b) Lee, P.-S.; Fujita, T.; Yoshikai, N. J. Am. Chem. Soc. 2011, 133, 17283. (c) Ding, Z.; Yoshikai, N. Angew. Chem., Int. Ed. 2012, 51, 4698. (d) Fallon, B. J.; Derat, E.; Amatore, M.; Aubert, C.; Chemla, F.; Ferreira, F.; Perez-Luna, A.; Petit, M. J. Am. Chem. Soc. 2015, 137, 2448. (e) Wang, S.; Hou, J.-T.; Feng, M.-L.; Zhang, X.-Z.; Chen, S.-Y.; Yu, X.-Q. Chem. Commun. 2016, 52, 2709.

8 Mn: (a) Zhou, B.; Chen, H.; Wang, C. J. Am. Chem. Soc. 2013, 135, 1264. Fe: (b) Wong, M. Y.; Yamakawa, T.; Yoshikai, N. Org. Lett. 2015, 17, 442.

9 Ru: (a) Chinnagolla, R. K.; Jeganmohan, M. Eur. J. Org. Chem. 2012, 417. Rh: (b) Parthasarathy, K.; Jeganmohan, M.; Cheng, C.-H. Org. Lett. 2008, 10, 325. (c) Patureau, F. W.; Besset, T.; Kuhl, N.; Glorius, F. J. Am. Chem. Soc. 2011, 133, 2154. (d) Muralirajan, K.; Parthasarathy, K.; Cheng, C.-H. Angew. Chem., Int. Ed. 2011, 50, 4169. (e) Ackermann, L.; Lygin, A. V.; Hofmann, N. Angew. Chem., Int. Ed. 2011, 50, 6379. (f) Wang, F.; Qi, Z.; Sun, J.; Zhang, X.; Li, X. Org. Lett. 2013, 15, 6290. Ir: (g) Tsuchikama, K.; Kasagawa, M.; Endo, K.; Shibata, T. Synlett 2010, 97. (h) Nagamoto, M.; Nishimura, T. Chem. Commun. 2014, 50, 6274. (i) Nagamoto, M.; Yamauchi, D.; Nishimura, T. Chem. Commun. 2016, 52, 5876. Re: (j) Kuninobu, Y.; Kawata, A.; Takai, K. J. Am. Chem. Soc. 2005, 127, 13498. (k) Kuninobu, Y.; Tokunaga, Y.; Kawata, A.; Takai, K. J. Am. Chem. Soc. 2006, 128, 202.

10 For oxidative annulation reactions, see: (a) Fukutani, T.; Umeda, N.; Hirano, K.; Satoh, T.; Miura, M. Chem. Commun. 2009, 5141. (b) Li, B.-J.; Wang, H.-Y.; Zhu, Q.-L.; Shi, Z.-J. Angew. Chem., Int. Ed. 2012, 51, 3948. (c) Shi, X.-Y.; Li, C.-J. Org. Lett. 2013, 15, 1476. (d) Chen, S.; Yu, J.; Jiang, Y.; Chen, F.; J. Cheng, Org. Lett. 2013, 15, 4754. (e) Chidipudi, S. R.; Khan, I.; Lam, H. W. Angew. Chem., Int. Ed. 2012, 51, 12115. (f) Zhang, X.; Li, Y.; Shi, H.; Zhang, L.; Zhang, S.; Xu, X.; Liu, Q. Chem. Commun. 2014, 50, 7306.

11 (a) Ebe, Y.; Nishimura, T. J. Am. Chem. Soc. 2015, 137, 5899. (b) Hatano, M.; Ebe, Y.; Nishimura, T.; Yorimitsu, H. J. Am. Chem. Soc. 2016, 138, 4010. (c) Yamauchi, D.; Nishimura, T.; Yorimitsu, H. Chem. Commun. 2017, 53, 2760. (d) Ebe, Y.; Onoda, M.; Nishimura, T.; Yorimitsu, H. Angew. Chem., Int. Ed. 2017, $56,5607$.

12 The alkene geometry of 3aa was confirmed to be $(E)$ by X-ray crystallographic analysis. See the Supporting Information.

13 The reaction of $\mathbf{1 g}$ with $\mathbf{2 a}$ (1.1 equiv) in the presence of $[\operatorname{Ir}(\mathrm{OH})(\mathrm{cod})]_{2}(2 \mathrm{~mol} \% \mathrm{Ir})$ at $70{ }^{\circ} \mathrm{C}$ for $1 \mathrm{~h}$ gave a mixture of monoalkenylated amide 3ga (85\%) and dialkenylated amide 4ga $(11 \%)$.

14 Ir: (a) Aufdenblatten, R.; Diezi, S.; Togni, A. Monatsh. Chem. 2000, 131, 1345. (b) Dorta, R.; Togni, A. Chem. Commun. 2003, 760. (c) Sevov, C. S.; Hartwig, J. F. J. Am. Chem. Soc. 2013, 135, 2116. (d) Shirai, T.; Yamamoto, Y. Angew. Chem., Int. Ed. 2015, 54, 9894. Sc: (e) Song, G.; O, W. W. N.; Hou, Z. J. Am. Chem. Soc. 2014, 136, 12209.

15 Imamoto, T.; Sugita, K.; Yoshida, K. J. Am. Chem. Soc. 2005, $127,11934$.

16 Hatano, M.; Nishimura, T.; Yorimitsu, H. Org. Lett. 2016, 18 , 3674. 